\title{
Moments of Obsolescence
}

\section{Competences and Career Life Cycles Revisited Through Information Society Policies}

\author{
Paula Ochôa ${ }^{* 1}$, Leonor Gaspar Pinto ${ }^{2}$ \\ Nova University of Lisbon \\ Portugal

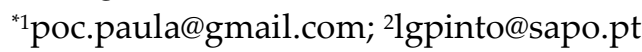

\begin{abstract}
This article examines the concept of moments of obsolescence in the library and information profession based on twelve career stories (career biographies) narrated by professionals working in Portuguese libraries since 1970 and 1980 with several and different professional transitions through Information Society developments and policies. We intend to highlight the importance of two cycles Information Life Cycle and Competence Life Cycle - by establishing connections between them in four major phases: information creation, distribution, seeking and utilization. Two topics - library and use - are combined with skills perspective and related to professional transitions, giving special attention to the major European policies towards Information Society, which have originated moments/risks of obsolescence in three areas: Technologies, learning and competence Finally, we pointed to the need to have a competency lifecycle framework for a wider variety of career stages, supporting the new approaches of theory of career construction and the studies of the relationships of information competences, career transitions and information processing paradigm as they evolve and causes another type of obsolescence impacts.
\end{abstract}

\section{Keywords}

Obsolescence; Information Society; Transitions; Career Management; Library and Information Professionals

\section{Career and Competence Obsolescence: Effect or Cause of Transitions?}

The inter-relationship between career selfmanagement, competence management, employability and obsolescence is considered a positive perspective in the current analysis of skills debate within Information Society (Arthur et al., 2005; Graf, 2012). Other contemporary advances in career research have resulted in new perspectives and paradigms for career construction, addressing working issues such as contextual possibilities, dynamic processes, non-linear progression, multiple perspectives and personal patterns (Savickas, 2012) where knowledge, understanding, practical and thinking skills are needed to perform effectively, regardless of the nature, type, size and complexity of work tasks. Within the theory of career construction (Savickas, 2002, 2005 and 2012), the term career means reflection upon activity, that is, reflection upon competences (objective career) and career transitions (subjective career) linked to identity and self-image. An emerging concept is career adaptability (Savickas, 1997) defined as "the capability of an individual to make a series of successful transitions where the labour market, organization of work and underlying occupational and organizational knowledge bases may all be subject to considerable change" (Bimrose et al., 2011, p. II).

Adaptability is a personal strategy (concern, control, curiosity, confidence, commitment) to avoid the risks of skill obsolescence and job insecurity over the life course highlighting the importance of life-long learning, considered as an important investment in human capital (Allen \& de Grip, 2007). The role of learning in developing career adaptability at work was studied by the UK Commission for Employment and Skills in 2011, with results in four dimensions (Bimrose et al, 2011):

1. Learning through challenging work (roles and processes)

2. Cognitive focus (involving updating a substantive knowledge base)

3. Communicative focus (comprising learning through and beyond interactions at work)

4. Learning as facilitator (individuals becoming more self-directed and self-reflexive in their learning and development).

Value and quality of competences are important elements in career self-evaluation and are related to transitions cycles, embedded turning points by various contexts, political and economic climate, interests, abilities, geography, age and gender. It should be noted that subjective experiences and 
evidences of changes are important elements to understand these processes. Since life course research has indicated an intensified individualization and diversification in life patterns, different individual approaches to career transitions points must be studied and identified by analyzing transitioning styles and meanings that individuals place on their career paths. However, there are few empirical studies on the effects of transitions patterns. One example with special meaning in Information Profession studies is Willis 1 (Workforce issues in Library and Information Science - Marshall, J.G., Solomon, P., \& Rathbun-Grubb, 2009; Marshall et al., 2010).

Different transition types have emerged in sociological and vocational studies, as identified in Table 1.

TABLE 1 CAREER TRANSITION TYPES

\begin{tabular}{|c|l|}
\hline Transition type & \multicolumn{1}{|c|}{ Example } \\
\hline Academic cycles & $\begin{array}{l}\text { Events resulting from the beginning/end of } \\
\text { academic studies. }\end{array}$ \\
\hline $\begin{array}{c}\text { Personnal } \\
\text { development cycles }\end{array}$ & $\begin{array}{l}\text { Events resulting from balancing decisions } \\
\text { between familiar life and career. }\end{array}$ \\
\hline Learning cycles & $\begin{array}{l}\text { Events resulting from learning styles } \\
\text { developed in formal/informal contexts, } \\
\text { personal and group contexts. }\end{array}$ \\
\hline Identity cycles & $\begin{array}{l}\text { Events resulting from change in } \\
\text { Professional identity linked to roles, tasks, } \\
\text { organizations and profession. }\end{array}$ \\
\hline Competence cycles & $\begin{array}{l}\text { Events resulting from transition periods and } \\
\text { from competence development. }\end{array}$ \\
\hline Creativity cycles & $\begin{array}{l}\text { Events resulting from intellectual } \\
\text { production and innovation initiatives. }\end{array}$ \\
\hline Obsolescence cycles & $\begin{array}{l}\text { Events resulting from skills not utilized; } \\
\text { skills needed but not available (skills gaps } \\
\text { and mismatch). }\end{array}$ \\
\hline
\end{tabular}

Savickas (2011, p.4) found that professionals should learn how to make the best investments in their current competences willing adaptation and development of new competences and stressed the need to research what factors are determinants in that process, showing that "people self-concepts may be altered by new experiences and even by observing the behavior of others. Their interests are never completely fixed and the self is continuously reconstituted".

Life career concerns the interactions of the work role with other life roles over the life course. Similarly, it is also well documented that many transitions in life are caused by changes in Information Society and its consequences on professions.One of the career features is informational behavior with the enormous range of information exchange and use activities through multiple informal and formal channels and different patterns of information processes.
Individuals in several life areas develop multiple information sub-cycles.

The complexity of Information Society influences on library and information career and competences management implies the adoption of current professional strategies and new approaches focused on a lesser-known cycle - obsolescence and its moments, characterized as a discontinuous dimension of knowledge needed to maintain effective performance (Cedefop, 2010).

\section{Obsolescence and Age}

Obsolescence is a topic examined in aging studies (Phoenix \& Sparkes, 2010), using a range of ways to analyze work stories. Narrative inquiry is one of those tools, providing alternative maps to the "narrative of decline" (Gullette, 2004) and investigating the similarities and differences over the life course. Expertise at older age and medium age are studied as an identity construction, but also focusing on the forms of acquiring and sustaining it. The list of events narrated give meaning to professional experiences, organize temporal cycles of skills and can produce a comprehension of career decisions about obsolescence moments. How age influences these meanings is another perspective of research (Grenier, 2012), exploring the ability to continuously reinvent skills (Arnseth, Gilje \& Erstad, 2012). Research on adult life transitions is underdeveloped being important to recognize that learning can help transitions at different levels: "each individual faces increasingly differentiated trajectories through their lives resulting from the particular constellations of transitions, and their various outcomes, which they experience. And these individualizing tendencies reinforce the absence of a completed, prescribed script for many of the transitions, habit and routine no longer provide a reliable guide to decision-making" (Field, 2012, p.8-9). The processes through which different cohorts transition obsolescence moments can illustrate the risks, vulnerability and agency in lives. Agency is a formal principle of the life course, implying the competence of future planning and decision making as crucial for individualized transitions (Marshall, 2011). Periods of the life course in which new roles are acquired are analyzed as dynamic transitions between the institutions and life spheres of society (Heinz \& Marshall, 2003). Katariina Salmela Aro (2009) describes an interesting and useful lifespan model of motivation in the context of critical life transitions the $4 C^{\prime}$ s: 
- Channeling - goals are inscribed within an opportunity space, constrained by sociostructural factors and age-graded environments.

- Choices - psychological factors active in the definition of developmental paths.

- Coagency - the articulation between sociostructural and psychological factors

- Compensation- readjustment to reach desired outcomes.

As Heinz (2009) reinforces, biographical choices are neither made freely nor with clear preferences, but rather reluctantly in respect to likely risks. Some of those risks become evident in public policy developments linked to employability, health, education and social assistance.

One of the major objectives of the European Employment Strategy, despite large discrepancies that still exist between countries, is to increase the overall employment rate involving older workers, supporting the sustainability of the social protection system and delaying the transition from work to retirement. A transitional labour markets perspective (Schmid \& Gazier, 2002) is growing, combining negotiation and enhanced mobility and transferability of skills between professions. It implies to draw a typology of transitions and related policies in a life course perspective: transition between employment and inactivity, transitions between employment and unemployment, within employment (full time, part time work). This vision is complemented by the Lifelong Learning Strategy that offers the potential for integrating formal education and training with informal and experiential development and an important policy in promoting labour mobility in three senses: vertical (career progression); horizontal (movement between sectors); and spatial (mobility in European countries). Routes to learning can consider learning types (explicit, accidental/incidental, implicit), environmental conditions (formal or non-formal) or organizational learning (single loop learning/ double loop learning) and knowledge development. Cyclical models of learningintegrating the linkages between the two types of learning can demonstrate how they are influenced by the formation of mental models and routines, as well by proficiency and experience. A range of dimensions/factors is required to maintain high levels of skills and competence: ability, knowledge, understanding, action, experience and motivation (Winterton, Delamare-Le Deist \&
Stringfellow, 2005)

\section{Collective Professional Strategies to Avoid Obsolescence}

Professional policies are extending this dynamic through the creation of competencies frameworks. This is also visible in the library and information profession in the last years: Euroguide LIS (ECIA); Body of Professional Knowledge (CILIP); Shaping the Future: ASRL's Competencies for Research Librarians; Competencies for Information Professionals (SLA); Guidelines on Cultural Work within the Information Society (European Council); Guidelines for Professional Library/Information Educational Programs (IFLA); Bibliofil - Le referentiel de la filière bibliothèque (DPMA); Core Competencies of Librarianship (ALA); Career Pathways (ALIA); The skills, Role and Career Structure of Data Scientists and Curators: an Assessment of Current Practice and Future needs (JISC); Competency Index for the Library Field (OCLC); Federal Librarians Competencies (Library of Congress); Library and Information Science Education 2.0 Project, Core Competencies for 21st century (Carl librarians); New Roles for New times: Digital Curation for Preservation. The intention behind these documentsis to ensure that professional bodies apply rigorous methodologies that provide tools that individuals and organizations can use to develop, assess and recognize competences that information professions are expected to possess.

Future directions are an important discussion topic in academic and professional agendas (Broady-Preston \& Cossham, 2010), which hosts the reflexive behaviour of some national libraries on holistic and strategic issues revision, anticipating collective trends: the British Library 2020 vision (British Library Board, 2010), the National Library of Wales 2020 strategy (National Library of Wales, 2010), the National Library of Scotland 2030 planning; the New Zealand National Library document New Generation Strategy to 2017 and the project $A$ vision for the academic library and information services of the future (2010-2011) carried out by the British Library, the Joint Information Systems Committee (JISC), the Research Information Network, the Research Libraries UK and SCONUL.

A globalised and digitised world through Cultural and Creative Industries (CCI) implies another kind of obsolescence, linked to moments of creation, production and reproduction, promotion and marketing, distribution and access and to moments of consumption - all of them transformed by technologies, 
platforms, formal and informal practical and conceptual skills, and new audiences, communities and transnational networks of users/consumers and creators/producers of creative practices and contents (Mercer, 2011). These obsolescence moments require multidisciplinary, interdisciplinary and "joined-up" approaches, thinking and training beyond the current skills set and a strong need to improve information on skills development and priorities (Mercer, 2011). In the creative work, management by project offers emancipatory possibilities, enhancing worker initiative and creativity in organizational and institutional contexts. These conditions and experiences need to be studied also in the librarian profession (Hodgson \& Briand, 2013; Hesmondhalgh \& Baker, 2011; Gallie, Zhou, Felstead \& Green, 2012; Thomas \& Chan, 2013).

\section{Obsolescence Moments in Information, Competences and Career Life Cycles}

Previous research in library and information careers (Ochôa \& Pinto, 2009) demonstrates that dynamics of continuous novelty and uncertainty, caused by Information Society environments can originate several obsolescence moments. Organizational studies highlight some processes like socialization and role transitions as most common obsolescence situations narrated by professionals. The European Centre for the Development of Vocational Training warns about the risk of skill obsolescence as consequence of old age, lack of organizational support for learning, job design and low participation in continuing training.

Based on twelve career stories (career biography) narrated by professionals working in two Portuguese librarians cohorts: cohort $A$ integrating librarians and other information professionals working since 1970 and cohort $B$ integrating librarians librarians and other information professionalsworking since 1980 (Ochôa, 2012). With several and different professional transitions narrated, we aimed to examine the relationships between information cycles importance in individual careers and individual competence cycles dynamics to understand when obsolescence moments are perceived. The complex nature of the links reported gave rise to our key research question:

- What kind of obsolescence moments does different library and information professional cohorts perceive?

To explore this question, we first considered the relationship between individual and information cycle tasks and career related competences developed over time, encompassing a broad and variable group of self-evidences about obsolescence events. Changes in one area may have a reciprocal impact on the other areas. Therefore, it is important to ensure their alignment, which would give a frame of reference for managing expectations and determine a better library and information career management.

Our data suggested that obsolescence moments occurs when changes in information processes and tasks implies new ways of working and new skills, crossing all the stages of career. Most participants were confronted with these moments when they perceived their performance as inadequate by comparing themselves with others or by self-assessment facing Information Society dynamics (Table 2).

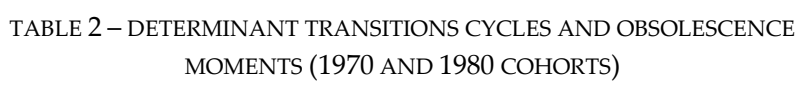
MOMENTS (1970 AND 1980 COHORTS)

\begin{tabular}{|c|l|l|} 
Cohorts & $\begin{array}{c}\text { Determinant } \\
\text { Transitions cycles }\end{array}$ & \multicolumn{1}{c|}{ Obsolescence moments } \\
\hline 1970 & $\begin{array}{l}\text { Competence cycles, } \\
\text { namely in the 80s } \\
\text { and 2000s }\end{array}$ & $\begin{array}{l}\text { Skills mismatch due to individual } \\
\text { gaps and job design } \\
\text { - Under skilled face to information } \\
\text { society demands }\end{array}$ \\
\hline \hline 1980 & $\begin{array}{l}\text { Academic cycles and } \\
\text { competence cycles }\end{array}$ & $\begin{array}{l}\text { Skills mismatch due to } \\
\text { organizational context } \\
\text { - Over skilled alternate with under } \\
\text { skilled face to information society } \\
\text { dynamics }\end{array}$ \\
\hline
\end{tabular}

\section{Competency Life Cycle Framework}

Given the conceptualization of obsolescence moments as a general and cyclical event towards one's career, we predicted indirect effects on perceived employability. We analyzed the data in two steps. In a first step, we focused on life-phases and we suggest that the Information Life Cycle is determinant to analyze obsolescence moments, representing another research opportunity that will allow us to generate new insights into the dynamics of library and information profession.

A model was conceived to illustrate a Competency Life Cycle framework (Figure 1). Conceptually,this model was developed following the Information Life Cycle (Borgman, 1996) with four major phases: creation, distribution, seeking, and utilization. These phases are aligned with the competence life cycle phases and roadmap (Behrens et al., 2012) - assess, plan, acquisition and validation - and four career main cycles - novice, intermediate, expert and active ageing-, establishing possible obsolescence moments experienced by our sample. 


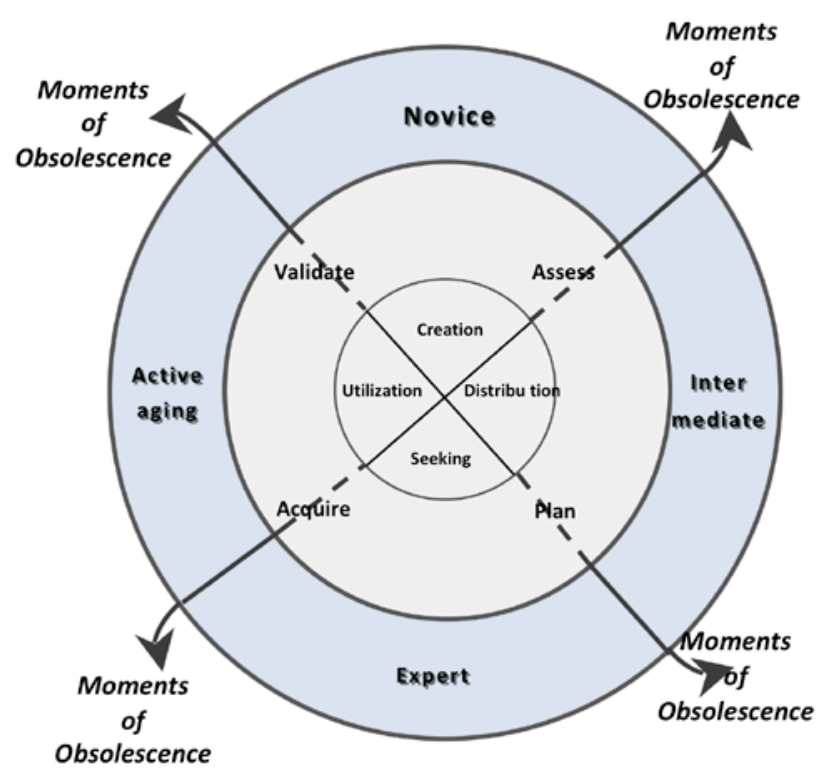

FIGURE 1 - COMPETENCY LIFE CYCLE FRAMEWORK

Library and information professionals have improved their skills in the information life cycle, discovering and gaining access to the information (web-based resources, bibliographic search, retrieval tools, on-line publications) for a variety of purposes, but they were also aware of the need of being up-to-date, which was seen as moments of obsolescence. The choice of information tools and resources is another field in which they don't have time to review the whole information landscape (receiving, generating, handling and managing huge volumes of information and data). Providing individuated professional support (advice and training) needs revised professional strategies and it is a challenging competence cluster. Rss feeds, podcasts, social bookmarks and other social networking tools require time management, which is not yet considered a priority. Creation activities, information flows, analytical tools and utilities introduced in their desktop environment were also mentioned as moments of obsolescence. Digital data management competences constitute another area of concern. Given the informational contexts in which they developed competences sometimes it was difficult to assess new competences and determinate a plan or to acquire expertise, but it was generally mentioned the strong difficulty to validate library and information competences at organizational level. This difficulty was considered a potential barrier to library and information competences visibility in society and an enabler to future moments of obsolescence. This trend is recognized at the European debate about digital age, namely the need to develop new competences (new business models and revenue streams, marketing and audience-building skills, ICT skills) and better knowledge about changes in information science sector. It is suggested that it will be a good strategy develop networking and exchange of practice and peer learning in a creative and cultural work without boundaries, based on sufficient information and data for evidence policy development.

\section{Transition Framework}

In a second step, we considered how two topics library and use - combined with skills perspective can be related to professional transitions. To do this, special attention was given to the major European policies towards Information Society (Pinto\& Ochôa, 2013), which have originated moments/risks of obsolescence in three areas: Technologies, Learning and Competence (Table 3).

\section{Transition I (1984-1994) Identity Cycles}

Cycle 1986-1994 - transition to EU performance trends - We can find a phase of recognition of specialized skills processes inspired by European libraries. All types of librarians are listened and participate in several plans. It's a cycle of development of identity.

\section{Transition II (1994-2000) Academic and Learning Cycles}

Cycle 1998-2000 - transition to Information Society national agenda- recognition of librarians as partners in the process of building the Information Society in Portugal: the risks of obsolescence are strong and one way to avoid them is to return to university and formal training, developing academic and learning cycles.

\section{Transition III (2000-2010) Competence Cycles}

Cycle 2002 -2005 - transition to e-government policy librarians reinforce their role and skills in the conceptualization and development of individual performance models through competence cycles associated with self-evaluation.

Cycle 2005-2010 - transition to the Technological Plan and strong alignment with 2010 - librarians as information managers and a need to improve technological skills.

\section{Transition IV (2010- ) Creativity Cycles}

Cycle 2010 - transition to a digital agenda. In a time of financial crises, the sector is facing a very relevant challenge. There is a need to re-think the cultural system 
TABLE 3 - INFORMATION SOCIETY EUROPEAN LANDMARKS AND MAJOR TRANSITIONS IN TWO COHORTS OF LIS PROFESSIONALS

\begin{tabular}{|c|c|c|c|c|c|}
\hline & \multicolumn{2}{|c|}{ TOPIC } & \multicolumn{3}{|c|}{$\begin{array}{c}\text { MOMENTS/RISKS OF } \\
\text { OBSOLESCENCE }\end{array}$} \\
\hline & Library & Use & $\mathbf{T}$ & $\mathbf{L}$ & $\mathrm{C}$ \\
\hline 1973 & & Dialog (online information system) & $\mathrm{x}$ & & \\
\hline \multicolumn{6}{|c|}{ TRANSITION I -Identity Cycles } \\
\hline 1984 & Schwencke Resolution & & $\mathrm{x}$ & & \\
\hline 1985 & $\begin{array}{l}\text { Resolution Collaboration between libraries in } \\
\text { the field of data processing }\end{array}$ & & $\mathrm{x}$ & & \\
\hline 1988 & $\begin{array}{l}\text { Plan of Action for Libraries in the European } \\
\text { Community(1988-1994) }\end{array}$ & & & $\mathrm{x}$ & $\mathrm{x}$ \\
\hline 1989 & & Information Market Policy Action (1989-1990) & $\mathrm{x}$ & & $\mathrm{x}$ \\
\hline 1990 & Libraries Programme (1990-1999) & & $\mathrm{x}$ & $\mathrm{x}$ & $\mathrm{x}$ \\
\hline 1991 & Telematics for Libraries (1991-1998) & & $\mathrm{x}$ & & $\mathrm{x}$ \\
\hline 1992 & & Maastricht Agreement & $\mathrm{x}$ & & \\
\hline 1994 & & $\begin{array}{l}\text { Bangemman Report } \\
\text { European Commission on Preservation and Access }\end{array}$ & $\mathrm{x}$ & $\mathrm{x}$ & $\mathrm{x}$ \\
\hline \multicolumn{6}{|c|}{ TRANSITION II - Academic and Learning cycles } \\
\hline 1997 & & $\begin{array}{l}\text { Digital heritage and Cultural Content Culture } 2000 \\
\text { eTen (1997-2006). } \\
\text { Livro Verde para Sociedade da informação }\end{array}$ & $\begin{array}{l}x \\
x \\
x\end{array}$ & $\mathrm{x}$ & $\begin{array}{l}x \\
x\end{array}$ \\
\hline \multirow{2}{*}{1998} & & Information Society Technologies (1998-2002) & $\mathrm{x}$ & $\mathrm{x}$ & \\
\hline & Standards & Standards & & & $\mathrm{x}$ \\
\hline 2000 & & $\begin{array}{l}\text { Lisbon Strategy } \\
\text { CAF } \\
\text { eEurope } 2002 \\
\text { Culture } 2000(2000-2006) \\
\text { eContent }(2000-2005)\end{array}$ & $\mathrm{x}$ & $\begin{array}{l}x \\
x \\
x \\
x\end{array}$ & \\
\hline \multicolumn{6}{|c|}{ TRANSITION III - Competence cycles } \\
\hline 2001 & & TEL - European Library & $\mathrm{x}$ & & $\mathrm{x}$ \\
\hline 2002 & & $\begin{array}{l}\text { eEurope } 2005 \\
\text { European research area, 2002-2006 }\end{array}$ & $\mathrm{x}$ & & $\mathrm{x}$ \\
\hline 2005 & & $\begin{array}{l}i 2010 \\
\text { Europeana }\end{array}$ & $\begin{array}{l}\mathrm{x} \\
\mathrm{x}\end{array}$ & & $\mathrm{x}$ \\
\hline 2007 & & LIBER-EBLIDA Digitisation Road Map & $\mathrm{x}$ & & \\
\hline 2010 & & European Digital Agenda (2010-2020) & $\mathrm{x}$ & & $\mathrm{x}$ \\
\hline \multicolumn{6}{|c|}{ TRANSITION IV - Creativity cycles } \\
\hline
\end{tabular}

Legend: Moments/risks of obsolescence: T-Technologies obsolescence $\mathbf{L}$ - Learning obsolescence $\mathbf{C}$ - Competence obsolescence

today in the face of a global economic crisis. The role and skills of librarians is uncertain and is dependent on performance evaluation. At the same time, opportunities to explore, develop and exchange experiences are growing. Measures of success are faceted across several categories: users, audience and stakeholders; Innovation and development; Internal processes and financial benefits and outcomes in a movement of convergence in culture and information environments thinking hybridization as a process of integration and fragmentation, particularly during periods of unusual transition, contingency and negotiability. These periods or cycles require a different understanding of how the new cycle of creativity at work.

\section{Discussion and Future Research}

In this paper, we developed a life-course model to study obsolescence moments in professional transitions among librarians and other information professionals in Portugal. The model consisted of four transition cycles, which were defined around Information Society developments in Europe. Findings suggest that obsolescence moments are important stages in professional career and can explain activity patterns over the life course. Thus, whilst there is recognition that identity, academic, learning and creativity cycles are the most frequently reported major transitions, it is clear that these first findings must be confirmed in other cohorts. The data collected from this framework is one prerequisite for further modeling skills gap analysis.

In future work, we hope to extend our research by studying careers that transcend libraries, archives and museums boundaries as a creative field, identifying new competence challenges and possible obsolescence 
moments.

Finally, there are a number of issues to be addressed through an interdisciplinary discussion. These include:

- Case studies about library and information communities: to identify obsolescence moments as a critical issue in career and competence management, promoting the debate and new training policies to sustain career capital and improve organizational performance.

- Development of organizational performance models that take account of human capital indicators to support emerging roles and competences, as well as strengthening informational skills as an important indicator of organizational value.

- Development of a better conceptual understanding of creative work, continuing to expand the number and variety of CCI studies.

- Study professions within the development of transitional labour markets.

- Generational analysis in professions of skills value, highlighting the variety of intergerational biographies in work.

We suggest that the Competency Life Cycle framework is positioned to focus future research on the relationships of information competences, career transitions and information processing paradigm as they evolve and causes another type of obsolescence impacts. In what concerns certification models, it should be used an integrated approach, contemplating competency clusters and meta-competencies, linked to obsolescence criteria. Such approach may chart a large range of diverse individual career capital selfevaluations and point to the importance of reflecting and managing obsolescence cycles since career beginning.

\section{ACKNOWLEDGEMENTS}

We would like to thank Professor Purificación Moscoso Castro (University of Alcalá, Spain) for her comments during the development of the study (20112012).

\section{REFERENCES}

Allen, J.; Grip, A. de (2007). Skill obsolescence, lifelong learning and labor market participation. Maastricht: Maastricht University.
Arnseth, H. C; Gilje, O., and Erstad, O. (2012). “Trajectories of learning lives: continuities and discontinuities in lifelong learning across contexts."Lifelong learning in Europe1 (2012): 12-19.

Arthur, M. B., Khapova, S. N., and Wilderom, C. P. M. (2005). “Career success in a boundaryless career world."Journal of Organizational Behavior26 (2005): 177-202.

Banks, M.,and Hesmondhalgh, D. (2009). "Looking for work in the creative industries policy." The international journal of cultural policy15 (2009): 415-430

Behrens, S.G., et al. (2012). Competency lifecycle roadmap. Toward performance readiness. Hanscom: Canergie Mellon University, 2012.

Benson J and Brown M (2007). "Knowledge workers: what keeps them committed; what turns them away."Work, Employment and Society 21, 1 (2007): 121-141.

Bimrose, J.,et al. (2011). The role of careers adaptability in skills study. London: UK Commission for Employement and skills, 2011.

Borgman, C. (1996). “Social aspects of digital libraries." In E. A. Fox; G. Marchioninni, Eds.Procedings of the $1^{\text {st }}$ ACM International conference on digital libraries. Bethesda, 170-171.

Broady - Preston, J., and Cossham, A. (2010). Mandatory CPD and professional revalidation schemes and their role in motivating and re-energising information professionals: the UK and New Zealand experiences. In Retention and job satisfaction: can professional development make a difference?, World Library and Information Congress, 76th IFLA General Conference and Assembly, 10-15 August, 2010, Gothenburg, Sweden. Accessed January, 10， 2012.http://www.ifla.org/en/conferencessession-day/2010-08-14.

Cedefop (2010). The skill mismatch: analyzing skill mismatch and policy implications. Luxembourg: EU Publications office, 2010.

Cronin, B., and Meho, L.I. (2007). “Timelines of creativity: a study of intellectual innovators in Information Science."Journal of Information Science58, 13 (2007): 1846-1958.

Davenport, T.H. (2005). Thinking for a living. How to get better performance and results from knowledge workers. Boston: Harvard Business School Press, 2005. 
Felstead, A., Gallie, D., Green, F., and Zhou, Y. (2007).“Skills at Work, 1986 to $2006 "$ "Project funded by ESRC Centre on Skills, Knowledge and Organisation Performance. Accessed October, 26 , 2013. http://kar.kent.ac.uk/4845/1/2006_Skills_SurveyFinalDraft3.pdf.

Felstead, A., Gallie, D., Green, F., and Zhou, Y. (2010). "Employee involvement, the quality of training and the learning environment: an individual level analysis". International Journal of Human Resource Management 21, 10 (2010): 1667-1688.

Field, J. (2012). “Transitions and lifelong learning: signposts, pathways, road closed?"Lifelong Learning in Europe 1 (2012): 5-11.

Gallie D, Zhou Y, Felstead A and Green F (2012). “Teamwork, skill development and employee welfare."British Journal of Industrial Relations 50, 1 (2012): 23-36.

Graf, A. (2012). "Life cycle oriented personnel development". Lifelong Learning in Europe1 (2012): 20-30.

Grenier, A. (2012). Transitions and the lifecourse: challenging the constructions of growing old. Bristol: The Policy Press, 2012.

Gullette, m.M. (2004). Aged by culture. Chicago: University of Chicago press, 2004.

Heinz, W. R (2009). Structure and agency in transition research. Journal of Education and work, 22 (5), 391-404.

Heinz, W. R., and Marshall, V.W., eds. (2003). Social dynamics of the life course: transitions, institutions, and interrelations. New York. Aldine de Gruyter, 2003.

Hesmondhalgh, D., and Baker, S. (2011). "'A very complicated version of freedom' Conditions and experiences of creative labour in three cultural industries."Variant 4 (Spring, 2011): 34-37.

Hodgson, D. and Briand, L. (2013). "Controlling the uncontrollable: 'agile' teams and illusions of autonomy in creative work."Work, employment and society0, 0 (2013): $1-18$.

Marks, A, and Baldry, C (2009). "Stuck in the middle with who? The class identity of knowledge workers."Work, Employment and Society 23, 1 (2009): 49-65.

Marshall, J.G., Solomon, P., and Rathbun-Grubb, S., eds. (2009). “Workforce Issues in Library and Information
Science [special issue]."Library Trends58,2 (2009).

Marshall, J.G., et al., eds. (2010). “Workforce Issues in Library and Information Science, part 2 [special issue]."Library Trends 59, 1-2 (2010).

Marshall, V.W. (2011). Risk, vulnerability, and the life course. Inaugural presentation. Lausanne: Lives Working paper 2011/1.

Mercer, C. (2011). “Which skills for culture in a globalised and digitised world?"European Culture Forum 20 (21 October 2011).

Ochôa, P. (2012). Transições profissionais na sociedade de informação: percursos identitários e ciclos de competências de bibliotecários portugueses (1973-2010). PhD thesis submitted at the Universidad de Alcalá (Spain). Accessed November , 13, 2013.

http://dspace.uah.es/dspace/bitstream/handle/10017/1710 9/TESIS\%20PAULA\%20OCHOA.pdf?sequence=1.

Ochôa, P. and Pinto, L. G. (2009). "Career, skills and dillemas." In Varlejs, J., and Walton, G., eds.Strategies for regenerating the library and information profession. München: K. G. Saur, 2009: 342-354.

Phoenix, C.; Smith, B.; Sparkes, A.C. (2010). “Narrative analysis in aging studies: a typology for consideration".Journal of Aging Studies 24 (2010): 1-11.

Pinto, L.; G.; Ochôa, P. (2013). “Information Society and library evaluation transitions in Portugal: a metaevaluation model and frameworks (1970-2013)". Liber Quaterly 22 (2013).Accessed October, 8. 2013. http://liber.library.uu.nl/index.php/lq/article/view/8264/9 735.

Salmela-Aro, K. (2009). "Personal goals and well-being during critical life transitions: the $4 \mathrm{C}^{\prime} \mathrm{s}$ - channeling, choice, co-agency and compensation."Advances in Life course research 14 (2009): 63-73.

Savickas, M. (2002). “Career construction: a developmental theory of vocational behavior." In D.A. Brown. ed.Career choice and development. San Francisco, CA: Jossey, Bass, 2002: 149-205.

Savickas, M. (2005). "The theory and practice of career construction." In S.D. Brown and R.W. Lent, edsCareer development and counseling: Putting theory and research to work. Hoboken, NJ: John Wiley \& Sons, 2005.

Savickas, M. (2012). “Life design: a paradigm for career 
interventions in the $21^{\text {st }}$ century."Journal of Counselling and development 90 (2012): 13-19.

Schmid, G. and Gazier, B., eds (2002) “The dynamics of full employment: social integration by transitional labour markets." London: Edward Elgar Publisher., 2002.

Thomas, K, and Chan, J. (2013). Handbook Of Research On Creativity. Edward Elgar Publishing, 2013.

Warhurst, C. and Thompson, P. (2006). "Mapping knowledge in work: proxies or practices?".Work, Employment and Society 20, 4 (2006): 787-800.

Winterton, J., Delamare-Le Deist, F., and Stringfellow, E. (2005). Typology of knowledge, skills and competences: clarification of the concept and prototype. Thessaloniki: Cedefop, 2005.

Paula Ochôa Lisboa, 1963- . Degree in History (Universidade de Lisboa, Portugal, 1985), Post-graduation in
Librarianship (Universidade de Lisboa, Portugal, 1988), MSc in Information Management (University of Sheffield, UK, 1994), PhD in Library and Documentation Sciences (Universidad de Alcalá, Spain, 2012).

Head of Information and Documentation Department of the Portuguese Ministery of Education (1996-2011). Senior librarian at the National Library of Portugal.

Researcher. Invited Professor at Nova University of Lisbon.

Leonor Gaspar PintoLisboa, 1965- . Degree in History (Universidade Nova de Lisboa, Portugal, 1987), Postgraduation in Librarianship (Universidade de Lisboa, Portugal, 1990), MSc in Information Management (University of Sheffield, UK, 1993), PhD in Library and Documentation Sciences (Universidad de Alcalá, Spain, 2012).

Head of Documentation and Information Division of the Portuguese Commission for Citizenship and Gender Equality since January 2013.

Researcher. Invited Professor at Nova University of Lisbon. 